\title{
Informal Cross-Border Trade Sarawak (Malaysia)-Kalimantan (Indonesia): A Catalyst for Border Community's Development
}

\author{
Abd Hair Awang ${ }^{1}$, Junaenah Sulehan ${ }^{1}$, Noor Rahamah Abu Bakar ${ }^{1}$, Mohd Yusof Abdullah ${ }^{2}$ \& Ong Puay Liu ${ }^{3}$ \\ ${ }^{1}$ Center for Social, Development and Environmental Studies, Universiti Kebangsaan Malaysia, Bangi, Malaysia \\ ${ }^{2}$ Center for Media and Communication Studies, Universiti Kebangsaan Malaysia, Bangi, Malaysia \\ ${ }^{3}$ Institute of Ethnic Studies, Universiti Kebangsaan Malaysia, Bangi, Malaysia
}

Correspondence: Abd Hair Awang, Center for Social, Development and Environmental Studies, Faculty of Social Sciences and Humanities, Universiti Kebangsaan Malaysia, 43600 UKM Bangi, Selangor, Malaysia: Tel: 60-3-8921-5481. E-mail: hair@ukm.my

Received: January 30, 2013 Accepted: February 26, 2013 Online Published: March 28, 2013

doi:10.5539/ass.v9n4p167 URL: http://dx.doi.org/10.5539/ass.v9n4p167

\begin{abstract}
Cross-border entrepreneurship activity plays an important role in the community economic development programs. The emergence of business groups and trade activities will generate employment, create wealth, contribute to tax revenue and stimulate the construction of infrastructures such as transportation. Indirectly, this will improve the standard of living in the border communities. The cross-border trade activities between Sarawak (Malaysia)-Kalimantan (Indonesia) continued to grow significantly. Although there is no formal cross-border route and Checkpoint of Immigration and Quarantine (CIQ) exists, Serikin as a small border town has developed as a Weekend Market focuses on informal trade. Indonesian traders and Malaysian consumers gathered on weekends to carry out transactions and this triggers local development. This article discusses the cross-border informal trade activities by focusing on the business participation factors and reasons for location selection, especially among Indonesian traders and spillover effects on the local communities.
\end{abstract}

Keywords: community development, informal cross-border trade, entrepreneurship, spillover, mouse paths

\section{Introducation}

The value of imports from Indonesia to Sarawak (Malaysia) was slightly reduced to MYR456.1 million in 2010 compared MYR474.0 million in 2009. However, the exports of Sarawak (Malaysia) to Indonesia reached MYR349.2 million in 2009 and continued to increase significantly (Department of Statistic, Malaysia 2010, 2011). Most of the population of Sarawak (Malaysia)-Kalimantan (Indonesia) border zone lives in villages and small towns. They are farming communities, and until 1993, the communities exchange their commodities at the border because they are being isolated from the business center (Obidzinki, Anrianto \& Wijaya, 2007). Rural economic development requires a systematic planning program to create jobs and enhanced the real income of the local community (Cummings, 2002; Dahl-Østergaard, 2003; Summers, 1986). Two approaches have been used to develop rural communities. The first approach is industrial development and the second approach is self-development. Rural industrial development was implemented in Malaysia in the early 1970s through multi strategies to stimulate the economy by creating chains of upstream and downstream manufacturing, processing, and transportation activities that lead to the trading of local raw materials, products and services (Arshad \& Shamsudin, 1997). The self-development approach brings along logic and scientific knowledge to farming communities to assist them on how to use their land efficiently (Abu Bakar et. al., 1977; Bradfield, 1966; Jones \& Garforth, 1997). Every individual desire for a better quality of life and they appreciate a new method for solving their daily problems towards a better standard of living (Van den Ban \& Hawkins, 1990). The backwardnesss of the farming communities resulted from the lack of knowledge to identify problems and alternative solution. Farmers do have knowledge but are not related to what they should have and are often influenced by the culture of the community. The community requires the dissemination and adoption of new innovation and technology (Abu Bakar et al., 1977; Seevers et al., 1997). Boone (1985) believes that the communities can be empowered by improving their knowledge and develop their minds as well as restructuring their existing knowledge. The slogans helping people help themselves and learning by doing will be included in the rural communities guiding programs (Abu Bakar et al., 1977; Mohd Nasir et al., 1984; Seevers et al., 1997). Hence, this approach emphasizes on the 
principle of developing rural communities through extension activities with the aim of spreading innovation, guiding and training communities to develop themselves and also their communities. This strategy is often refereed to as the Total Community Capital. The Total Community Capital includes human capital, infrastructure, natural resources and social capital (Cartwright \& Gallagher, 2002). Human capital refers to technical and non-technical knowledge including leadership. According to Johnson and Santos (2003), the six types of capital, that is, policy, physical, financial, human, cultural and social capital can be used to improve the standard of living of the rural communities.

\section{Informal Cross-Border Trade}

In Malaysia, the development of rural entrepreneurship programs started in 1970 when the government introduced the New Economy Policy (NEP) (Ahmad, Wan Yusoff, Md Noor \& Ramin, 2011). With the emergence of business groups and trade activities will generate employment, create wealth, contribute to tax revenue, and stimulate the construction of infrastructures such as transportation (Christy \& Dassie, 2000). Entrepreneurs act as a mediator who combine resources to generate output or products and services. Therefore, it can be seen that entrepreneurship activities become the basis for the community's economic development. A study done by Myer-Ohle (2009) showed that shopping activities played an important role in the redevelopment of cities in Japan and Singapore. Cross-border trade activities benefited the traders on both sides of the borders. This provided an opportunity for traders to gain new markets, source of supply, capital, labor and technology, although the type of opportunity received is influenced by the level of economic development of both borders. According to Blatter 2000, cross-border trading contribute to the economic development of an area. In fact, this activity brings them out of the vicious cycle of poverty (Damon \& Jeuring, 2009; Muzvidziwa, 2001; United Nations, 2010) and improves the families' socioeconomic status and becomes the main source of income to the family (Damon \& Jeuring, 2009; United Nations, 2010). Cross-border business activities in South Africa and Zimbabwe not only enabled them to have a comfortable place to stay (Damon \& Jeuring, 2009; Muzvidziwa, 2001) but it also enhanced the level of education and health for themselves and the family (Damon \& Jeuring, 2009). According to Titeca (2009), cross-border informal trade can be one of the mechanism to develop the economy of the local community. Rural border community development based on entrepreneurship in Malaysia received relatively less attention and are not being explored sufficiently (Ibrahim Ngah, 2010). This article discusses the cross-border informal trade activities by focusing on the participation factors and selection of strategic location, especially for the traders from West Kalimantan. This article will also highlight the spillover effects on the local communities.

\section{Methodology and Research Area}

The location of this research is in Serikin, Sarawak, Malaysia. Serikin is a small, remote town, but is busy on the weekends. The town is located about 5 kilometers from the border of West Kalimantan, Indonesia. The majority of the community living in Serikin is the video community, an ethnic group categorized under the Dayak group living in rural areas. Analysis about the trading activities in Serikin is done using survey and face-to-face interviews with the respondents. There are about 186 traders and only 51 traders provide complete and useful information. In-depth interviews were also conducted with the villages, village leaders and local business community leaders, based on snowball technique. In-depth interviews were carried out to understand the trading activities that are being carried from the trader's perspective. Ackello-Ogutu (1996) had defined commodities that crossed the national borders through unofficial routes without inspection from the custom officers can be categorized as an unrecorded trading and is informal in nature. Because there is no formal cross-border routes or Customs and Immigration International Checkpoints (CIQ) in Serikin, this study categorized the trading activities as informal.

Serikin town has a small immigration post, custom office, police station, and a military camp. It is their responsibility to ensure the illegal movement of people and goods are under control. Most of the border communities used trails or mouse paths (jalan tikus) for cross-border labor immigration, trading (smuggling) various commodities and visiting relations. These movements occur without valid passes which the locals regarded as the traditional routes. Following the 1967 Basic Agreement between Malaysia and Indonesia, it was decided that border communities living in the immediate border areas on either side were to be allowed to cross the border for short, non-work-related visits. However, a cross between borders need a Border Crossing Pass (Pas Lintas Batas), locally known as the red letter/book (surat merah or buku merah). The Pas Lintas Batas enables the Indonesians or Malaysians to cross the international border without official passports. With the Pas Lintas Batas, movements are limited to within $30 \mathrm{~km}$ of the border areas.

\section{Results}

\subsection{Profile of Cross-Border Traders}

Serikin started with a small-scale barter trade in the early 1980s. Now, it has become the focal point of local 
communities and traders from Indonesia to sell their merchandise over the weekend. This small town becomes an open-space hyper-supermarket and offers a variety of goods with relatively cheap prices. The products sold are predominantly fabrics and garments $(27.5 \%)$, vegetables and local fruits $(9.8 \%)$, beverages $(9.8 \%)$, furnitures, handicrafts and herbs (7.9\%), and electrical and household goods (3.9\%). The business site is located on the left and right side of the road for about 200 meters long. The stalls are simple, made of wood and roofed with zinc and leaves. Traders are charged MYR80.00 per month for a stall rental. The visitors to this Weekend Market come on Saturday and Sunday from 8 am to $5 \mathrm{pm}$.

Research showed that most of the traders are Indonesians who comes from various part of West Kalimantan. The majority of them are from Pontianak (56.9\%) and Sangau Ledo (13.7\%). About 17.7 percent is from Singkawan, Pemangkat, Seluas and the nearby border villages. They came either using their own cars, rental vans, or trucks which are parked on the Kalimantan border. It takes them about three to eight hours drive to reach Serikin town. Although the traders are from the interior part of West Kalimantan, they are confident and highly motivated to carry out their business activities. The same situation happened in the study carried out by Muzvidziwa (2001). There were only four local Serikin traders and one trader from Tebedu, Sarawak. The small number reflects the low participation of local traders versus the number of traders from Indonesia. Most of the traders were men (62.7\%), and $37.3 \%$ were female between the ages of 20 and 55 . The same situation occurs to cross-border trade in Tanzania's neighboring countries (Ackello-Ogutu \& Echessah, 1998), Western and Eastern Hungray (Momsen, Szorenyi \& Timar, 2005), and South Africa-Mozambique (Peberdy \& Crush, 2001) whereby the traders were dominated by men.

Traders are always associated with marginality and the struggle for survival. According to Alusala (2010) and Mijere (2009), informal traders are often assumed to be poorly educated. However, the result of the research in Serikin is similar to the studies carried out by Peberdy (2000) and Peberdy \& Crush (2001). It was found that $11.8 \%$ of the traders had obtained university education, $45.1 \%$ had an upper secondary school education, $11.8 \%$ had a lower secondary school education, $21.6 \%$ had a primary school education, and the remaining $7.8 \%$ had not attended school. A total of $78.4 \%$ of traders had 6-10 years of business experience. Approximately about $72.0 \%$ of the traders used their own saving as a start-up business capital. Only $28 \%$ of the traders received financial support from family members, friends and banks. None of them used money laundering or borrow from private money lenders. According to the traders, it is not worthwhile to borrow from private money lenders because of the high risks associated with repayment. The two Bidayuh business leaders from Serikin also stated that there are no guarantees for the "Ah Long" (private money lenders) to receive loan repayments from Indonesian traders.

According to one of the respondents, a local trader who rented out the business space, the estimated monthly average profit was MYR 2,000 (USD500). The restaurant owners who are locals received on a monthly average net profit of MYR840 (USD210). Furniture, herbs and handicraft products, based primarily on the rattan and wild plants owned by Indonesian traders, gained higher profits. Textile and apparel traders who are mostly Indonesian, received an average net profit of MYR589 (USD147) per month. The agro-based business (vegetables and fruits) and electrical goods earned only between MYR250-300 (USD60-75) per month. Only two local traders sold vegetables and fruits while all electrical goods traders were Indonesian. Indonesian traders frequently crossed the border to earn higher profits, and they priced their goods higher than they would have in their home countries. The Ukrainian-Romanian (Cassidy, 2011), India-Bangladesh (Sikder, 2005), and Uganda (Titeca, 2009) informal cross-border traders also profit from the price differences across borders.

\subsection{Determinants of Trade Participation}

Respondents were asked as to why they are involved in trading. Maslow (in Hamilton \& Harper, 1994) mentioned that motivation for high achievement encourages traders to move forward. Traders with high aspirations always set their targeted goals and seek alternatives to overcome trade challenges (McClelland, 1961). Table 1 presents the reasons for traders to be involved in cross-border trading. The main reasons are interested in business, gain better income and prefer to be self-employed. The same situation occurs in the research carried out among informal cross-border traders between South Africa and the neighboring countries (Peberdy, 2000) and Eastern external European Union borders (Bruns, Miggelbrink \& Muller, 2011) whereby respondents are also primarily driven by the income-earning opportunities available. The involvement of informal cross-border trade between Mozambique and its neighbours is also to gain extra income whilst informal cross-border traders in Zimbabwe are mainly driven by friendship (Muzvidziwa, 2001). The highest unemployment rate in the home countries (Niger, 2009) also encourages Indonesian traders to be engaged in business activities, so that they can help to sustain their family needs. Being able to gain high profit from the trading activities had encouraged traders to routinely cross the borders. For example, in South Africa, $50 \%$ of the informal traders use cross-border trading as their main source of income, and 22\%-24\% of them use this activity as a source for their side income (Damon \& Jeuring, 2009). 
Table 1. Economic and socio-psychological factors for engaging in cross-border trade

\begin{tabular}{lclc}
\hline Reasons & Percent & Reasons & Percent \\
\hline Gain extra income & 47.1 & Interested in business & 62.7 \\
Self-employed & 37.3 & Wanted to try & 21.6 \\
No other jobs & 27.5 & Having the business skills & 19.6 \\
Business opportunities & 15.7 & Work environment & 11.8 \\
Low starting capital & 5.9 & Inherit family business & 7.8 \\
Easy to get supplies & 3.9 & Cannot receive directions from the boss & 11.8 \\
\hline
\end{tabular}

\subsection{Determinants of Location}

Table 2 showed that traders prefer to carry out business in Serikin because they are familiar with the space provided $(23.5 \%)$ by the locals. This factor had become the main attraction for informal cross-border traders. Furthermore, there is a high demand from Malaysian consumers (17.6\%), especially during weekends. The low average cost of rental space of MYR60-80 (USD15-20) per month also encourages the growth of cross-border trade. The low rate of room rental at MYR5 per day encourages traders to stay longer in Serikin town. Rooms are also available to store goods for an average rental of MYR40 per month. Most of the Indonesian traders leave their goods and returned to their villages after doing their business on Sunday evening. Their willingness to come again the following week is very high because they believe that the Weekend Market provide opportunities for them to gain a better income. At the border, there is a military guard post to monitor traders and individuals. Many traders come to Serikin town on Friday afternoon and return home on Sunday afternoon. Simple custom, police and immigration procedures have also encouraged Indonesia traders to do business activities in Serikin town. The Cross-Border Pass obtained from the Indonesian government facilitates the movement of traders to the Malaysia-Sarawak border.

Table 2. Determinants of doing business in Serikin

\begin{tabular}{lclc}
\hline Reasons & Percent & Reasons & Percent \\
\hline Availability of business space & 23.5 & Availability of infrastructure (roads) & 7.8 \\
Focus on customers & 17.6 & Friends/relatives involved in business & 3.9 \\
Low cost of rental space & 13.7 & Availability of supply & 2.0 \\
Easy cross-border procedures & 13.7 & Direction from the authority & 2.0 \\
Close to home & 11.8 & Safety guaranteed & 2.0 \\
\hline
\end{tabular}

The majority of traders stated that they are very satisfied with the trading activities carried out in Serikin town. This is driven by the road accessibility between Serikin and other towns or villages, despite deterioration of the road and the distance of the trip which takes between 8 and 12 hours. Cross-border traders at the Kenya-Uganda and Rwanda-Burundi borders face similar difficulties in transportation networks and infrastructure (United Nations, 2010). In addition, traders from West Kalimantan feel that the business space being provided at a low rate had helped them to continue doing their business. From the interviews conducted among the traders, on average, they agree that the business opportunities in Serikin are more secure than the markets next to their border area. Locals trust the Indonesian traders to carry out their businesses. Previous research carried out at several places such as Zimbabwe-South Africa (Muzvidziwa, 2001), Uganda-Rwanda (Alusala, 2010), India-Nepal (Taneja \& Pohit, 2002), and Romania-Ukraine (Cassidy, 2011) borders showed that cross-border traders are encouraged to carry out business activities due to safe locations and low business costs. These traders also have family relationships with the local communities. Family networks and kinship enables them to obtain support and input for their business (Krackhardt, 1992). The similarity of dialect, culture, customs, beliefs and family ties strengthen these cross-border trade networks. The phenomenon of family relationships also exists across the India-Bangladesh (Ghosh, 2011) and Finnish-Swedish borders (Paasi \& Prokkola, 2008). It is even easier to build new relationships with local communities or strengthen the relationships with other new traders (Nardi, Whittaker \& Schwarz, 1999). An overall average net profit of MYR700 per month (USD175) motivates traders to make 
Serikin a permanent trade location. However, Indonesia traders are also faced with competition. Their competitors are among their Indonesia colleagues who sell the same products at the same location. However, more than half of the traders did not face major problems. According to the traders, the most important factor for their business success are sufficient capital, strategic location, interest and demand for their products.

\subsection{Spillover to Local Communities}

Communities of villages along the borders received benefits from the business activities that is being carried out. Local traders set up stalls and leased them to the Indonesia traders for MYR60-80 (USD15-20) a month. They also made the open space available in their house compound as parking space for rent. There are many restaurants and food stalls opened for business, and at the same time there are private houses being rented to Indonesian traders for MYR5.00 (USD1.50) per night. For storage of goods, there was an additional charge of MYR70 (USD20.00). Some Indonesian traders bought household items such as sugar, cooking oil, cookies and other processed food for domestic consumption from the local traders because sugar is much cheaper in Malaysia than Indonesia due to government subsidies (Dissing et al., 2010). Private toilets were built behind the shop houses and the private houses and the charges made for the public are MYR0.20 cents to MYR0.50 cents for a bath.

According to the local communities, the development of Serikin town had provided job opportunities and indirectly had improved their standard of living. The local municipal council charges each stall MYR 5.00 per day for the cleaning-up of rubbish at the weekend market. Based on interviews with villagers, village leaders and local business community leaders, the socioeconomic status of the local communities has improved since Serikin became a border market. Although the military recognizes the existence of smuggling between the borders using the traditional routes (mouse paths), but there is no statistical evidence. The spillover of traders from Kalimnatan at Serikin market had influenced the nearby villages such as the set-up of tamu at Kampung Duyuh. The majority of the stalls at the tати managed by women selling handicrafts, plants, wild orchids, fruits, vegetables and forest products. Some of the products sold at the tamu are acquired from the Serikin market itself. This scenario clearly showed that the villages and markets at the border depend on each other for survival.

\section{Conclusion}

This study clearly showed the dominance of traders and commodities moving from Kalimantan, Indonesia to Serikin, Sarawak. The economic and sociocultural factors give a strong impact to the involvement of the Indonesian traders to carry out business activities at the Malaysia-Indonesian borders. The existing family relationship also encourages the trade activities to be carried out between the two borders. It can be seen that cross-border trade stabilizes the market price of the goods supplied with the additional demand from the recipient country and provide job opportunities. However, in terms of tax collection, it is affected by the probability of not paying taxes, as mentioned by Ackello-Ogutu and Echessah (1998), Alusala (2010), Lesser and Moise-Leeman (2009), Macamo (1999), Peberdy (2000), Sikder, (2005) and Titeca \& de Herdt (2010). The implication of cross-border trade also have spin-off activities, including human trafficking, smuggling of migrants, the spread of infectious diseases and crime as experienced in Laos, Combodia, Vietnam and Thailand (Paitoonpong, 2007) and at Uganda-Rwanda border (Alusala, 2010). A systematic cross-border security, well-planned infrastructure and a good trade transaction procedure will benefit both parties. Furthermore, state investments and comprehensive community development programs are required because communities living on the fringes of the border between two countries faced a myriad of issues that make them economically, socially and politically vulnerable. Through the intervention of the local municipal council and stakeholders, with effective regulations, tariffs and taxes, Serikin town will be able to remain as a mall within the forest and experienced positive spillover effects.

\section{References}

Abu Bakar et al. (1977). Extension in perspective: The Malaysian experience, Departmental conference on agriculture extension, Working papers.

Ackello-Ogutu, C. A. (1996). Methodologies for estimating informal cross-border trade in Eastern and Southern Africa, AMEX International Inc, UNSAID.

Ackello-Ogutu, C. A., \& Echessah, P. N. (1998). Unrecorded cross-border trade between Tanzania and herneighbors: Implication for food security. Technical Paper, (89), 1-99.

Ahmad, A. R., Wan Yusoff, W. F., Md Noor, H., \& Ramin, A. K. (2011). Preliminary study of rural entrepreneurship, Development program in Malaysia, International Conference on Management (ICM) Proceeding.

Alusala, N. (2010). Informal cross-border trade and arms smuggling along the Uganda-Rwanda border. African 
Security Review, 19(3), 15-26. http://dx.doi.org/10.1080/10246029.2010.519875

Arshad, F. M., \& Shamsudin, M. N. (1997). Rural development model in Malaysia, Paper presented to the Hon. President of Peru, Mr. Alberto Fujimori, Lima, PERU, 13 October.

Blatter, J. (2000). Emerging Cross-border Regions as a Step towards Sustainable Development? International Journal of Economic Development, 2(3), 402-439.

Boone, E. J. (1985). Developing programs in adult education. London: Prentice Hall.

Bradfield, D. J. (1966). Guide to extension training. Food and Agriculture organization of the United Nation: Rome.

Bruns, B., Miggelbrink, J., \& Muller, K. (2011). Smuggling and small-scale trade as part of informal economic practices. International Journal of Sociology and Social Policy, 3(11-12), 664-680. http://dx.doi.org/10.1108/01443331111177869

Cartwright, S., \& Gallagher, T. (2002). Total rural capital: A model to engage extension faculty and the public in rural community development. Journal of Extension Education, 40(6), 1-4.

Cassidy, K. (2011). Performing the cross-border economies of post-socialism. International Journal of Sociology and Social Policy, 31(11-12), 632-647. http://dx.doi.org/10.1108/01443331111177841

Chisty, R. D., \& Dassie, W. (2000). Enterpreneuship centered economic development: An analysis of African American entrepreneurship in the Southern BlacK Belt. Contractor Paper 00-10, TVA Rural Studies.

Cummings, S. (2002). Community Economic Development as Progressive Politics: Toward a Grassroots Movement for Economic Justice. UCLA Public Law Series, Los Angeles: UCLA School of Law.

Dahl-Østergaard et al. (2003). Community-driven rural development: What have we learned. Technical Papers Series, Washington D.C: Inter-American Development Bank.

Damon, M., \& Jeuring, K. (2009). Informal cross-border trade as an instrument alleviating poverty. Open Society Initiative for Southern Africa, 114-118.

Department of Statistics, Malaysia. (2009). Sarawak external trades statistics. Kuching: Sarawak.

Department of Statistics, Malaysia. (2010). Sarawak external trades statistics. Kuching: Sarawak.

Dissing et al. (2010). Livelihood strategies in Kpg Biawak, Sarawak. Kuching Sarawak: ILUNRM Report.

Eilenberg, M. (2009). Intersecting spheres of 'legality' and 'illegality': A case of cross-border labour migration in West Kalimantan, Indonesia. Paper presented at the Workshop on Labour Migration and Trafficking: Policy Making at the Border, co-organised by CAPSTRANS, University of Wollongong, Australia and Institute of Ethnic Studies (KITA), UKM, on 1-3 August, at UKM Bangi.

Ghosh, S. (2011). Cross-border activities in everyday life: the Bengal borderland. Contemporary South Asia, 19(1), 49-60. http://dx.doi.org/10.1080/09584935.2010.544718

Hamilton, R. T., \& Harper, D. A. (1994). The Entrepreneur in Theory and Practice. Journal of Economic Studies, 21(6), 3-18. http://dx.doi.org/10.1108/01443589410071391

Johnson, J. H., \& Santos, P. (2003, Fall). Fostering rural community competitiveness in a knowledge driven economy, Economic Development Journal, 46-58.

Jones, G. E., \& Garforth, C. (1997). The history, development and future of agriculture extension. In B. Swanson, R. P. Bentz, \& A. J. Sofranko (Eds.), Improving agriculture extension, Food and Agriculture organization of the United Nation. Rome.

Krackhardt, D. (1992). The strength of strong ties: The importance of philos in organizations. In N. Nohria, \& R. G. Eccles (Eds.), Networks and organizations (pp. 216-239). Boston: Harvard Business School Press.

Lesser, C., \& Moise-Leeman, E. (2009). Informal cross-border trade and trade facilitation reform in Sub-Saharan Africa. OECD Trade Policy Working Paper, No. 86. http://dx.doi.org/10.1787/225770164564

Macamo, J. L. (1999). Estimated of unrecorded cross-border trade between Mozambique and her neighbors: Implication for food security. USAID.

Mayer-Ohle, H. (2009). Two Asian malls: Urban shopping centre development in Singapore and Japan. Asia Pacific Business Review, 15(1), 123-135. http://dx.doi.org/10.1080/13602380802399445

McClelland, D. C. (1961). The Achieving Society. New York: The Free Press. 
Mijere, N. J. N. (2009). Informal and Cross-Border Trade in the Southern African Development Community, OSSREA.

Mohd et al. (1984). Extension strategies in Peninsular Malaysia; Issues and problems. In M. Sulaiman, I. B. Yassin, \& I. Mamat (Eds.), Improving extension strategies for rural development. Serdang: Universiti Pertanian Malaysia.

Momsen, J. H., Szorenyi, I, K., \& Timar, J. (2005). Gender at the border: Entrepreneurship in rural post-socialist Hungary. Aldershot: Ashgate Publishing Limited.

Muzvidziwa, V. (2001). Zimbabwe's cross-border women traders: Multiple identities and responses to new $\begin{array}{llllll}\text { challenges. Journal of Contemporary African } & \text { Studies, } & 19(1), & \text { 67-80. }\end{array}$ http://dx.doi.org/10.1080/02589000124044

Ngah, I. (2010). Rural development in Malaysia. Monograph no 5, Center for Innovative Planning and Development, Faculty of Built Environment, University of Technology Malaysia.

Obidzinki, K., Anrianto, A., \& Wijaya, C. (2007). Cross-border timber trade in Indonesia: Critical or overstated problem?, Forest governance lessons from Kalimantan. International Forestry Review, 9(1), 526-535. http://dx.doi.org/10.1505/ifor.9.1.526

Paasi, A., \& Prokkola, E. (2008). Territorial dynamics, cross-border work and everyday life in the

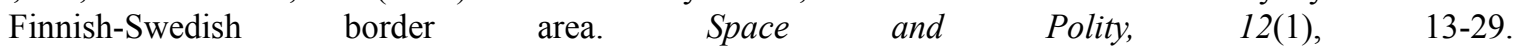
http://dx.doi.org/10.1080/13562570801969366

Paitoonpong, S. (2007). Thailand's cross-boder trade in the greater Mekong Subregion: Selected social issues. CCAS Working Paper no 9, Center for Contemporary Asian Studies, Doshisha University.

Peberdy, S. (2000). Mobile entrepreneurship: Informal sector cross-border trade and street trade in South Africa. Development Southern Africa, 17(2), 201-219. http://dx.doi.org/10.1080/713661400

Peberdy, S., \& Crush, J. (2001). Invisible trade, Invisible travelers: The Maputo Corridor Spatial Development initiative and informal cross-border trading. South African Geographic Journal, 83(2), 115-123. http://dx.doi.org/10.1080/03736245.2001.9713727

Seevers et al. (1997). Education through cooperative extension. Albany: Delmar Publishers.

Sikder, M. J. U. (2005). Livelihoods and informal trade at the Bangladesh border. Inter-Asia Cultural Studies, 6(3), 432-445. http://dx.doi.org/10.1080/14649370500170134

Summers, G. F. (1986). Rural community development. Annual Review of Sociology, 12, 347-371. http://dx.doi.org/10.1146/annurev.so.12.080186.002023

Taneja, N., \& Pohit, S. (2002). Characteristics of India' Informal and Formal Trading with Nepal: A Comparative Analysis. Indian Economic Review, 37(1), 69-89.

Titeca, K. (2009). The Changing Cross-Border Trade Dynamics between north-western Uganda, North-Eastern Congo and Southern Sudan. Working Paper no. 63, Institute of Development Policy and Management, University of Antwerp.

Titeca, K., \& De Herdt, T. (2010). Regulation, cross-border trade and practical norms in West Nile, North-Western Uganda. Africa, 80(4), 573-594. http://dx.doi.org/10.3366/afr.2010.0403

United Nation. (2010). Gender dimensions of cross-border trade in the East African Community: Kenya/Uganda and Rwanda/Burundi border, African Trade Policy Center.

Van den Ban, A. W., \& Hawkins H. S. (1990). Agricultural extension. Essex: Longman \& Scientific and Technical. 